University of New Mexico

UNM Digital Repository

History Faculty Publications

Scholarly Communication - Departments

1997

\title{
American Reform Efforts: German Professional Education after World War II
}

Charles E. McClelland

University of New Mexico, cemcc@unm.edu

Follow this and additional works at: https://digitalrepository.unm.edu/hist_fsp

Part of the History Commons

\section{Recommended Citation}

McClelland, Charles E.. "American Reform Efforts: German Professional Education after World War II." Jürgen Heideking, Mark Depaepe and Jurgen Herbst (eds.), Mutual Influence on Education: Germany and the United States in the Twentieth Century, Paedagogica Historica, New Series, 33 (1997), 265-75.] (1997). https://digitalrepository.unm.edu/hist_fsp/16

This Article is brought to you for free and open access by the Scholarly Communication - Departments at UNM Digital Repository. It has been accepted for inclusion in History Faculty Publications by an authorized administrator of UNM Digital Repository. For more information, please contact amywinter@unm.edu. 


\title{
American Reform Efforts: \\ German Professional Education after World War II
}

\author{
Charles E. McClelland \\ University of New Mexico
}

[Later published in Jürgen Heideking, Mark Depaepe and Jurgen Herbst (eds.), Mutual Influence on Education: Germany and the United States in the Twentieth Century, Paedagogica Historica, New Series, 33 (1997), 265-75.]

In 1945, German professionals faced the same suspicion and hostility as other elites of defeated National socialist Germany. Judges and lawyers had betrayed legal norms common to the civilized world; Nazi physicians had carried out sadistic experiments; German chemists and engineers had supplied Zyklon-B to the Holocaust death camps; teachers had inculcated obedience; and pastors had sanctified the regime. Had all professionals been corrupted by their forced organizational "Nazification" after 1933? Could one trust them?

Almost a half-century later, a history of German
professions from 1900 to 1950 stresses the "corrosion of German
professionalism" and attributes it to "a separation from its
liberal roots." Another equally recent study of German jurists


laments the hollowing-out of the liberal core of German law under Nazi rule: "The resulting damage has made itself felt in the intellectual climate of German jurisprudence up to the present day, and has proven to be one of the most lasting inherited defects."ii

Such judgments may be disputable, but they rest largely on hindsight. Considering that the Allied victors of 1945 started with similar suspicions of professional (as well as other) elites and announced ambitious, in some cases sweeping policies aimed at making them over into serviceable instruments of reconstruction, we might well wish to compare their intentions (foresight) with the judgments of the results (hindsight) mentioned above. The four powers differed considerably in the way they carried out their views, however. While referring to the other three occupying powers, this paper will focus mainly on the American. As the richest, most powerful and most influential power, its attempts at professional reform deserve special interest.

This chapter will limit itself to an exploration of educational reform and specifically to three areas in which the American occupation influenced the shape of professional education in the 1940s and beyond. First, it will briefly cover the effects of denazification. Second, it will examine the way 
in which American professional organizations expressed their concern about defects in German professional education, and what effects such concern had in Germany. Finally, it will address the way in which American occupation authorities dealt with the equivalents of U.S. professional organizations in Germany, since they had all had very concrete agendas for educational reform before the Third Reich.

First and most immediately, denazification processes reduced the sheer number of professional practitioners even below the decimated level already caused by Nazi policies and war losses. The opportunity of rapidly training replacements was severely limited by the same processes applied to the teaching staff of universities and technical colleges.

The history of denazification is relatively well-known and need not take up limited space here. It is important to note, however, that this "personnel policy" (or rather succession of policies) set important conditions and limitations on any chance for other reforms of professional education. The initial wave of dismissals and purges of Nazi party members produced severe shortages of trained personnel allowed to function in professional capacities, as well as in the higher educational institutions that were obliged to train the next generation. This was one of many "crisis phenomena" that reduced the chances 
for fundamental structural reform in the first few years of the occupation.

To put this another way: the Nazis had already greatly undermined the integrity of most professions, snatching back in many cases their promise of "reprofessionalization" once the war was on. (This promise had formed one of the most alluring "appeals of fascism" to professionals in 1933 who could otherwise not be reached by Nazi ideology.) Manpower shortages during the war led to the steady erosion of university teaching and study, just as university buildings were victims of heavy war damage; and of course the Nazis left Germany bankrupt. This situation would have been crisis enough to overcome in 1945; but the initial and rather hasty, ill-thought-out "denazification" prevented all extremes of party members, from hard-case fanatics to timid Mitläufer or so-called Karteigenossen, from teaching or exercising most other learned professions.

At the beginning of the Allied denazification process, personnel deficits (for example in university and technical college faculties) were made up in part by bringing back retired personnel. These were in some cases men (hardly any women) who had been forced out by the National socialist regime; but in most cases they were just old. People who had already served 
under the Weimar Republic and returned to office with the implicit assumption that they should carry on as before 1933 were hardly the most likely candidates for the role of fiery reformer. By the time Allied denazification processes had stopped (as in the Soviet Zone by 1947) or been radically modified (as in the American Zone), many persons with dubious pasts had now been allowed to resume their careers, thus solving some of the manpower shortage at the cost of reinstalling persons who were also unlikely to be on the forefront of calls for major changes in the way professional education was handled. (It is worth noting that the Soviet zone carried out both the most radical purge of Nazis as well as the most radical restructuring of professional education and the British perhaps the least in both areas.)

Although the American occupation brought with it initiatives for educational reform, these appear to have been pyramidal in shape: the lower the level of education, the greater the American interest. This chapter is based only on the most preliminary sifting of the evidence, but that indicates a pattern of pragmatism and ad-hoc decisions regarding higher education, not a well-thought out plan for reform brought to Germany along with Jeeps and C-rations. The impressive recent collection edited by Gary Tsushimochi, The U.S. Occupation of 
Germany: Educational Reform, 1945-1949, for example, contains over 1600 documents, almost none of which deals extensively with the reform of professional education. iii American concerns about and tangible contributions to higher education, such as studium generale or exchange programs, could usually be described as belonging to the "undergraduate" level.

In comparing the negative and positive "reform efforts" carried out initially under American occupation auspices in the universities, however, one can readily see that the former (denazification) was much easier to undertake than the latter. But let us examine briefly whether the occupation authorities could find blueprints for professional education reform supplied by such organizations as the American Medical and Bar Associations or similar associations of engineers or teachers. What does a preliminary survey of the American professional press during and immediately after the Second World War indicate?

As Duke University medical Professor Wilburt Davison reported, after touring German medical schools in the summer of 1945, they had "not kept pace with the advances in medicine" and German physicians were "poorly trained."iv Unfortunately, he also 
reported, most German medical professors were unwilling to acknowledge these charges or the need for significant reform. Davison argued that there were too many students, period, and also too many for the limited clinical and laboratory facilities. But a reduction in student numbers would have reduced the lecture fee income of the professors, whose own economic interests, he implied, militated against reform. ${ }^{\mathrm{N}}$

Davison's own preference was fairly clear and is worth citing in full because it shows no lack of understanding on the part of American educators about the need for sweeping reforms in professional education :

Complete denazification and reform with active American participation: Complete denazification of the university; rigid selection of students; reorganization of the curriculum to introduce laboratory and bedside teaching in place of the current lecture system; establishment of a uniform, short, practical final examination to replace the time-consuming staatsexamen; the payment of adequate teaching salaries with the university retaining all student fees; provision of supplements to German libraries and laboratories from American sources, and 
sponsorship of each opened German medical school in the U.S. zone by some American medical school, which probably, if invited, would rotate some of its faculty members to the German school so that modern teaching methods could be established and maintained. ${ }^{\text {i }}$

Somewhat cryptically, he predicted that this plan would prove impractical, however, both because German cooperation was uncertain and unspecified American and Allied "sources" might react adversely. ${ }^{\text {ii }}$ The plan favored by those "sources," he claimed, was "complete denazification without reform," that is "without reorganization of the curriculum, except for the elimination of Nazi ideology and of dangerous research activities."viii This was, in other words, the plan of the military authorities. Finally, the plan preferred by the German medical faculties was, according to Davison, "limited denazification without reform," or the removal only of personnel actually arrested by the authorities or removed by internal university committees. ${ }^{\text {ix }}$

These comments are even more interesting when one realizes they were gathered on an information trip sponsored by the medical authorities of the U.S. Control Group (Germany), in the company of such influential occupation-era educational advisors 
as Edward Hartshorne.

Almost three years later, another report on medical education in Germany, this time commissioned by the U.S. Surgeon General, still found it wanting in four out of five areas: welltrained faculty; suitable clinical and hospital facilities; adequate equipment and supplies for teaching laboratories; and a "well-selected student body." Only in the fifth area -providing an adequate volume and variety of sick patients -- was Germany doing extremely well! ${ }^{x}$ Even with a numerus clausus for medical study, perhaps half the university students were entering medicine, the author of this 1948 report speculated, mostly because many medical students were allocated extra rations above the 1500-calorie daily level. ${ }^{\mathrm{i}}$

With the easing of denazification strictures by 1948, one could conclude that the third of Davison's "alternatives", "limited denazification with no reform," had become the reality under American occupation, as least as far as medical education was concerned.

American attitudes toward reform in the legal profession appear also to have relied more heavily on denazification than educational change. Draconically, all German courts were closed 
at the beginning of the Occupation, with up to $90 \%$ of all legal personnel losing their jobs. xii Attempts to reopen courts from mid-1945 on proved difficult when not enough trained jurists with clean political records could be found even to staff the bench, and many of these were retirees in their $70 \mathrm{~s}$ and older. Instead of employing hastily and badly trained "people's judges," as in the Soviet Zone, the western Allies gradually relaxed strictures against all but the highest-level former NSDAP party members and office-holders (this was achieved especially in the American zone by the mechanism of amnesties), so that the required legal personnel could be largely drawn from what remained of the Third Reich's personnel (including numerous refugees from the east). ${ }^{\text {iii }}$ The final twist to this story was the restoration of the rights of pre-1945 civil servants, including judges and state's attorneys, in West Germany during the $1950 \mathrm{~s}$.

Did the American occupation authorities treat the German legal profession in a way significantly different from the expectations of their American professional colleagues? Judging by the relatively small body of literature reflecting the latter, it did not. The consensus American legal opinion appears to have been that, while German legal practice had been badly distorted by the imposition of Nazi ideology, extraordinary courts, over-harsh punishments, and practices contravening 
international standards, these had not penetrated very deeply into the legal profession! High and basically sound standards of legal training before 1933 were thought to have been the norm. The fact that a complete legal education (including postuniversity training) normally required up to 13 years, and the thousand-year Reich had only lasted 12, prompted some to argue that there were, strictly speaking, no German lawyers trained entirely under the Nazis. Others pointed out the fact that very few young men had been allowed to continue to study law once the war had begun (three years at the front being the condition for returning to study). ${ }^{\text {xiv }}$ In any case I could find no published demands in American legal circles for a thoroughgoing reform of legal education in Germany.

Considering the keen American emphasis on "re-education," one would expect a much different attitude toward the reform of the teaching profession in Germany. Indeed, the occupation authorities were also at pains to eliminate suspected Nazis from teaching posts, even though this led to terrible overcrowding in classrooms; and they were in principle interested in reforming the ideological training of teachers, especially those in the Volksschule and Realschule. In practice, however, the teacher training system found in the American occupation area in 1945 was largely left intact, once Nazi elements had been removed and 
the Weimar "essence" restored. Also in practice this meant no further steps toward "professionalizing" the training of lower and mid-school teachers by promoting university-level education for them -- one of the unfulfilled professionalizing desiderata of the more important Weimar teachers' professional organizations.

The professional press of American teachers before and immediately after the end of the war (like the ordinary American press) carried many articles on "German education after the war," but almost all of these addressed issues of "democratization" and school reform below the level of professional training. (One even made the plea that America should democratize its own schools before trying to do so in Germany!) •

Finally, combing the professional press of American engineering yielded practically no expressions of concern for the reform of technical professional training. The focus appeared rather, both before and after the end of hostilities, on a suspected superiority of German engineering and how, after 1945, it could be harnessed to America's interests. The expropriation of German "technical capital" (such as in the U.S. rocket program) is a vivid indication of the degree to which American engineers were more impressed by the need to learn from 
Nazi Germany than to introduce radical reforms into German technical colleges.

In a third area, an important set of clues to the expectations of the American occupation authorities regarding professional educational reform may be gleaned from American treatment of German professional organizations. Long before the end of World War II, such U. S. professional organizations as the American Medical and Bar Associations had a profound and certainly not-to-be-ignored voice in most matters affecting the shaping of American professions. How were their German equivalents approached for possible reform ideas?

Because the German equivalents had been gleichgeschaltet, and not simply abolished and forbidden outright, understandable doubt existed in the Allied occupation authorities' minds about the akademische Berufsverbände. Of course all those extant in 1945 were dissolved by all four powers as organizations affiliated with the Nazi Party, e.g. the NSRB (National Socialist Judges League), the NSÄB (National Socialist Physicians League) or the NSLB (National Socialist Teachers League). It did not appear to matter to the Allies whether the German professional associations already extant in 1932 had subsequently been abolished or forcefully absorbed in Nazi ones: 
all professional associations were prohibited by the Allies at first. They remained prohibited for the most part in the soviet zone; at the opposite extreme, the British were the first to drop their suspicions and promote the reestablishment of professional organizations, at least in their own zone.

The American authorities, however, had an additional reason for opposing professional organizations. They obviously were pinning their hopes on the alternative organizational model of labor unions to embrace professional workers and, in a broader sense, bring democratic ideas to all employed Germans at their workplace. The Americans were on solid historical ground in one sense: labor-union types of professional organization had already established themselves on German soil during and, incipiently, even before the Weimar Republic, although they had held limited appeal. In one very notable case, this American expectation met with success -- the GEW (Union for Education and Science). Still, it is ironic that the British zonal authorities -- operating under a radical Labor government -- chose to allow the non-union form of professional association, while the increasingly anti-leftist Americans preferred to push unions.

Thus reforms in such areas as curriculum, examinations and educational qualifications, in which the professional associations had played a noticeable role at least before the Hitler era, were undertaken by the American occupiers (if at 
all) without consulting those organizations.

Whatever their reasons, the American authorities' initial hostility to professional associations meant that the German professions had no real way of articulating reform ideas, including progressive ones. (Presumably anti-democratic and Nazi ideas would have been banned in any case.)

What tentative conclusions may we draw from this admittedly preliminary survey of American ideas about reforming German professional education?

(1) Especially in the light of today's assumptions about how the public in Allied countries felt about the evils of National Socialism, it is surprising how, during the war and immediate post-war years, relatively little public discussion found its way into the American professional press, either of the horrors of Nazification or of the pressing need to change the nature and structure of German post-Abitur education. Instead, there was a wide agreement that the damage Nazism had done was probably not permanent and could be eliminated largely by personnel policies, chiefly the denazification of the professoriate and student body. Regard for pre-1933 professional training remained high, and faith in the basic soundness of those older structures and traditions was pronounced. The German 
professions and their educational underpinnings were viewed more as victims than as breeding-grounds of Nazism.

(2) Even when the American professional press or special evaluating groups visiting Germany called for major changes in professional education -- as with medicine -- these tended to be more of a quantitative than qualitative nature. If German medical training needed to be reformed, for example, then more because it was perceived as "behind" rather than because medical schools had incidentally produced the largest percentage of a pre-1933 profession sympathetic to the Nazis. (Reform suggestions also sometimes reflected little more than ethnocentric preferences, for example for the "hospital" centered training of American and British medicine vs. the "lecture-hall" centered traditions of Germany.)

(3) Whatever the thoughts and suggestions of American professionals may have been, there is not much evidence that they were put into practice by the American occupation authorities. Denazification was all by itself a sufficiently formidable task for the occupation authorities; the goal of maintaining a minimal operating level in such institutions as universities, another desideratum of the American occupiers, pulled them in the other direction, even if the temperature-drop 
of the deepening Cold War and the quiet resistance of most Germans (including surprisingly many exiles from Hitler's Third Reich) had not also been forces pushing the same way. Lack of qualified personnel and other resources to oversee the restructuring of the higher educational system is obvious to anybody who studies this period. Under these circumstances, could the occupation authorities have undertaken sweeping reforms, even if the will to do so had been more strongly in evidence?

In this context, comparisons to British and French policy are instructive: despite the centralizing and active role of the French and the rather more "fraternizing" and hands-off stance of the British, the policies of all three Western occupying powers concerning university reform were quite comparable. The costs of reform from the ground up, administratively and in terms of financial support, were obviously too high to contemplate.

(4) If one can speak of a "restoration" in West German professional training and, more broadly, university life after 1945, it would appear to have fit in largely with the attitudes both of American professionals and the American occupation authorities. Far from seeing the Weimar professions and 
professional faculties producing "illiberal men," American professionals held them in surprisingly high regard and, even before the Germans themselves could claim to be "victims of Hitler," largely ascribed this role to their enemy colleagues.

(5) In a broader sense, "reeducation" or schooling in democratic virtues, another American concern, reflected more an interest in mass education than training at the top: in no way for which I can find significant evidence did the Americans advocate diluting the elite nature of tertiary (that is, for all intents and purposes, professional) education to achieve "democratization." It was more concerned with what values occupied the minds of this reformed elite. Despite the GI Bill, which really began to "democratize" American higher education at this time, at least on the college level, there was no perceptible concern to export the idea of expanded highereducational opportunity to occupied Germany. (If anything, overcrowding was the concern.)

The absence of a documentary trail of a comprehensive reform program for German higher education does not, of course, prove that Americans had little or no impact. What they did -with or without an overall plan -- surely had an impact and 
helped shape the system. Indeed, someday there will be a chance to compare their actions with those of the Federal Republic in the Neue Bundesländer after the GDR's "Stunde Null," and it would not be surprising to find the American record on real reform a strong one in comparison.

Historians are used to "the irony of reform." What is intended rarely comes out as hoped by those in a position to effect changes. Given the financial, administrative, globalideological, domestic political, and physical constraints on the American occupation authorities and their charges, German universities and technical colleges, among others, it is difficult to see how radical reforms could have been carried out. Even more clearly, however, there was no vocal constituency in the USA to force democratic attention to such reforms of professional education. American engineering journals, for example, were much too busy pointing out the absurdity of the Morgenthau Plan -- which threatened the very idea of professional technical education in Germany -- to insist on a radical reform of that education.

We should perhaps better think of the "irony of non-reform" and the laying of a foundation for a "restoration" of Weimar professional training without the discuptions, along with an 
injection of "democratization" and other environmental factors (such as prosperity and security) between 1945 and the 1960s. On these "American" foundations, reform would later be debated and carried out.

\section{NOTES}

i

Konrad H. Jarausch, The Unfree Professions. German Lawyers, Teachers, and Engineers, 1900-1950 (Oxford, 1990), p. 226. ii Ingo Müller, Hitler's Justice. The Courts in the Third Reich, translated by D. L. Schneider (Cambridge, MA: Harvard University Press, 1991), p. 297.

iii Gary H. Tsushimochi (ed.), The U.S. Occupation of Germany: Educational Reform, 1945-1949 360 microfiches (Bethesda, MD: University Publications of America, 1991).

iv Wilburt C. Davison, "The German University Medical Schools during the Occupation," Journal of the American Medical Association (hereafter cited as JAMA), 129 (1945), p. 1225. v Ibid.

vi Ibid.

vii Ibid.

viii Ibid.

ix Ibid.

x Irving S. Wright, MD, "Medical Education in Germany and Austria," JAMA, 137 (1948), p. 6.

xi Ibid., p. 8. An interesting sub-theme of Wright's report is obvious concern among U.S. doctors that German-trained physicians might be planning to emigrate to the USA someday and claim a right to licensure. Given the hostility of the American medical profession to even the forced immigrants from fascist Europe during the Depression, one might legitimately wonder to what extent this report might be biased by similar fears. xii Gerhard Fieberg (ed.), Im Namen des Deutschen Volkes. 
Justiz und Nationalsozialismus (Cologne, 1989), p. 353. xiii Cf. J. R. Wenzlau, Der Wiederaufbau der Juztiz in Nordwestdeutschland 1945 bis 1949 (Königstein, 1979), passim. The British zone's practice did not differ drastically from the American.

xiv See, for example, James V. Bennett, "The German Legal and Penal System," The Journal of Criminal Law and Criminology, 37 (1946-47), esp. p. 371; Friedrich Roetter, "The Impact of Nazi Law," Wisconsin Law Review, 1945 (1945), esp. pp. 545-51; and, for a comparable British view, Norman S. Marsh, "Some Aspects of the German Legal System under National Socialism," The Law Quarterly Review, 62 (1946), 366-74. 